Volume 13

Issue 3 Critical Genocide and Atrocity

Prevention Studies

$12-20-2019$

\title{
The First Lesson in Prevention
}

Alexander L. Hinton

Rutgers University

Follow this and additional works at: https://digitalcommons.usf.edu/gsp

\section{Recommended Citation}

Hinton, Alexander L. (2019) "The First Lesson in Prevention," Genocide Studies and Prevention: An International Journal: Vol. 13: Iss. 3: 128-144.

DOI:

https://doi.org/10.5038/1911-9933.13.3.1677

Available at: https://digitalcommons.usf.edu/gsp/vol13/iss3/11

This Articles is brought to you for free and open access by the Open Access Journals at Digital Commons @ University of South Florida. It has been accepted for inclusion in Genocide Studies and Prevention: An International Journal by an authorized editor of Digital Commons @ University of South Florida. For more information, please contact digitalcommons@usf.edu. 


\section{The First Lesson in Prevention}

\section{Acknowledgements}

I'd like to thank Andrew Woolford, Nicole Cooley, and the reviewers for their thoughtful comments and suggestions on this essay. I'd also like to thank Christian Gudehus, Susan Braden, and the team at Genocide Studies and Prevention for their efficient review of this essay and publication of the special issue in which it appears. My appreciation as well goes to the University of Manitoba and Rutgers Center for the Study of Genocide and Human Rights for co-sponsoring the workshop at which this essay and the larger special issue began to be formulated. 
The First Lesson in Prevention

Alexander Laban Hinton

Rutgers University

Newark, New Jersey, USA

\section{Critique}

Warning

"There's a Medusa in the room!"

Pig in a Poke

In prevention, we tell many tales. Most are tragic, stories of victims and their suffering and woe. But we seek out heroes, some tragic, some fortunate and a bit more bland. Lemkin is one. And then there are the resisters, rescuers, saviors, and saints.

Caveat emptor, it's said. "Let the buyer beware." So, too, the genocide scholar and preventer. Pig in a Poke! Are we tricking ourselves with our preventer stories, our hero and victim narratives? And how do we know?

Critical Prevention Studies provides one tool, the offering of this essay. But critique makes many people uneasy, especially those inclined to normative quest. "Too critical" some complain. "Negative!" Others pin the ultimate slight with a roll of the eyes: "Ivory Tower" musings. For some critique is Medusa-like, petrifying moral action. And perhaps it can be. But it's also possible the prevention quester is already on a petrified path, only partly seeing.

For the purposes of this essay, I refer to critique - and critical prevention studies by extension - as a methodology involving discernment, ambiguation, decentering, genealogy, openness, recursivity, and a look at the unsaid. Analysis if you will - but in the etymological sense of an unloosening. Denaturalization. Contextualization, Multivocality. And dare I say it? A bit of deconstruction.

Reread what I've written. Pig in a poke. The critical difference is already there. ${ }^{1}$ It was present in the first sentence. It's manifest in the writing style. You just need to read between the lines.

I'm going to tell you some critical prevention stories though they lack clear heroes, focus on blind spots and flaws. Some even involve me. We'll travel to ancient Greece, Norway, and Cambodia.

Go ahead. Read some more. Medusa is waiting. Turn the page. I dare you.

Medusa's Head

I promised Medusa. She was already lurking, but here's her tale. There are different versions, old (Hesiod and Ovid) and new (Bulfinch and Hamilton). And today her story is recounted on YouTube shorts and in comic book form.

Of course, she serves as a second act, the foil to Perseus's blade, as illustrated by the frequent framing of the retellings that have titles like "PERSEUS: The Hunt for Medusa's Head." "Could a monster whose gaze turns men to stone be the death of the son of Zeus?" one graphic narrative headlines. Another highlights: "Perseus ... the hero is ordered to slay a hideous monster named Medusa, whose gaze turns men into solid stone. How can Perseus fight an enemy he can't even look at? He will need the wisdom and weapons of the gods to prevail." ${ }^{3}$

There, in a nutshell, is the gist of the story in its popular form: the hero Perseus succeeds in his perilous quest to slay the monster Medusa. While varying in some of the details, the popular narrative follows a similar form. Here's a summary taken from two graphic narratives aimed at

\footnotetext{
${ }^{1}$ Barbara Johnson, "The Critical Difference," Diacritics, 8, no. 2 (1978), 2-9. For an overview of critical theory, see Verdeja and the editor introduction, this issue. Whigham, this issue, also discusses performance studies, which considers dramatic structure, character, juxtaposition, plot, utterance, and other issues that resonate with the focus of this essay. On the emergence of critical genocide studies, which intersects with critical genocide prevention studies in many ways, see A. Dirk Moses, "Toward a Theory of Critical Genocide Studies," Online Encyclopedia of Mass Violence, April 18, 2008, accessed November 9, 2019, http://www.sciencespo.fr/mass-violence-war-massacre-resistance/en/document/ toward-theory-critical-genocide-studies; Alexander Laban Hinton, "Critical Genocide Studies," Genocide Studies and Prevention 7, no. 1 (2012), 4-15, accessed November 9, 2019, https://scholarcommons.usf.edu/gsp/vol7/iss1/3/.

2 Paul D. Storrie, and Thomas Yeates, Perseus: The Hunt for Medusa's Head (Minneapolis: Graphic Universe, 2008$), 8$.

${ }^{3}$ Blake A. Hoena and Daniel Ferran, Perseus and Medusa: A Graphic Novel (North Manketo: Capstone, 2014), 2.
} 
teenagers. The treacherous King Polydectes sends heroic Perseus to do the impossible: to bring him the head of Medusa, whose hair of snakes and hideous gaze petrifies anyone who looks at her.

Perseus is helped by Athena, who bestows upon him gifts of the gods to aid in his quest: a magic sword, winged sandals, a helmet of invisibility, and a magic bag in which to place Medusa's head. Athena also gives him her shield. "Look only at her reflection in this shield," Athena advises Perseus, "and you will be safe." 4 She tells him that he can learn the whereabouts of Medusa's lair from the three Grey Witch sisters, who share an eye to see and tooth to eat.

After Perseus forces the Grey Witches to reveal Medusa's location by stealing their eye, Perseus travels to her lair, a place of ancient ruins where Medusa lives with her two Gorgon sisters. The dark compound is filled with petrified soldiers who had sought to kill Medusa. Looking into his reflective shield, Perseus succeeds in locating Medusa and cutting off her head, which he quickly puts into his magic bag and flees, barely escaping Medusa's irate sisters.

While passing through Ethiopia on his way home, Perseus sees Princess Andromeda, who is being sacrificed to appease Poseidon and prevent one of his sea monsters from wreaking havoc upon the kingdom of Andromeda's family. Perseus slays the sea monster and asks to marry Andromeda as his reward, a request that is granted. At the wedding, Andromeda's former suitor appears with an armed guard, which Perseus defeats by pulling Medusa's head out of the bag and petrifying them.

Upon returning home, Perseus does the same to King Polydectes and his guard when Polydectes tries to force Perseus's mother, Danaë, to become his wife. Perseus pays homage to Athena and gives her Medusa's head, which Athena mounts on her shield to terrify her enemies. The myth ends with Perseus fulfilling a prophecy that his mother's father, King Acrisius, would be killed by his grandson. In response, Acrisius had cast Danaë and the infant Perseus into the sea, where they were protected by Perseus's father, Zeus, who facilitated their rescue by Polydectes' brother. In the end, Perseus inadvertently kills his grandfather with an errant throw at an Olympic event.

Frame

"Medusa!" you may be asking. "What does this have to do with prevention?" But remember my first warning and the first lesson in prevention: "There's a Medusa in the Room!" Then I cautioned, "Pig in a Poke!"

Before I turn to my next story - and yes, it connects to Medusa as well - let me switch to a more expository frame. And indeed, "the frame" is a good place to start. Graphic narratives, in part due to the success of Maus, have increasingly been acknowledged for their literary qualities - as opposed to being "mere" commercial art, comics, cartoons, or "the funnies" - including the genre's similarity to poetry through its use of juxtaposition, visual image, materiality, and underlying grammatical structure (panel, text, and image). ${ }^{5}$

As I have suggested elsewhere, ${ }^{6}$ graphic narratives provide an entrée into critical genocide studies and, by extension, critical prevention studies. One way graphic narratives do so is through their compositional structure of sequential panels separated by borders called "gutters."

If this compositional style offers many ways to undertake critique, ranging from considerations of space and time (through the layout and visual structures that enable analysis of linear, emplotted moments and places), the gutter-frame structure highlights the process of foregrounding (whatever is highlighted in the panel) and backgrounding (through the ever-present gap between the frames suggesting erasure).

In other words, even as they assert given articulations, such as the popularized Perseus and Medusa myth summarized above, graphic narratives structurally and visually suggest the erasure

\footnotetext{
${ }^{4}$ Storrie and Yeates, Perseus, 8.

${ }^{5}$ Hilary Chute, “Secret Labor," Poetry Magazine. July 1, 2013, accessed November 10, 2019, https://www.poetryfoundation. org/poetrymagazine/articles/70022/secret-labor. See also Art Spiegelman, MetaMaus: A Look Inside a Modern Classic Maus (New York: Pantheon, 2011).

${ }^{6}$ Alexander Laban Hinton, “Wonder Woman, the Gutter, and Critical Genocide Studies," in Memory and Genocide: On What Remains and the Possibility of Representation, ed. Fazil Moradi et al. (New York: Routledge, 2017), 165-174.
} 
that inevitably accompanies them. Graphic narrative form, in other words, demands that we always ask what has been edited out, existing now only as a trace in the visually present gutters bordering the frames.

In Man or Monster? The Trial of a Khmer Rouge Torturer ${ }^{7}$ I have argued that this dynamic of (framing) articulation and the redaction that ensues - and "the redactic" potential for what has been edited out to dehisce - is part of the banality of everyday thought (a reworking of Arendt's idea of "the banality of evil" ${ }^{8}$ ) even as it may be mobilized by "thick frames of power" in contexts ranging from the torture chamber to international law.

What does this discussion tell us about the myth of Perseus? It suggests the first lesson of critical prevention: always look for the "Medusa in the room," a haunting and uncanny presence, often only glimpsed from traces, which needs to be critically discerned. And indeed, the myth's emphasis on the gaze is suggestive in this regard: the eye of the Grey witches, prophecy, the helmet of invisibility, and, of course, Medusa's petrifying gaze.

In both of the graphic narratives about Perseus and Medusa that I drew upon, eyes are also highlighted in the panels and the petrifying power of Medusa's head is signified by glowing light emanating from her eyes. This motif of the seen and the unseen - a worthy trope of critical prevention studies - is a key current in the myth of Medusa and one the graphic form is able to underscore in visual ways prose usually cannot. ${ }^{9}$

To conclude this first story, I want to turn to erasure and the gutter. What is the Medusa in the room in the myth of Perseus? Medusa provides a guiding clue. We have a hero and a monster whose monstrosity (her past petrifying violence) legitimates violence against her (her decapitation): Violence at Time (V1) (her past monstrous and petrifying acts) legitimates Violence at Time 2 (V2) (Perseus cutting off her head).

A host of questions are backgrounded, including Medusa's past. Where is she from? Why is she mortal while her Gorgon sisters are not? Why does she have the power of petrification? One of the graphic narratives completely ignores such questions, which otherwise disrupt the hero narrative. Perseus and Medusa: A Graphic Novel provides a passing reference to Medusa's more complicated past, when a young Perseus asks Dictys, Polydectes brother, to recount the story of Medusa.

"A long time ago, there was a beautiful woman named Medusa," Dictys begins. ${ }^{10}$ Poseidon fell in love with her and they "met secretly" in Athena's temple. Because Medusa bragged that she was more beautiful than even Athena, Athena "punished Medusa for her vanity," turning Medusa's "silken hair into slithering serpents ... soft hands into crooked claws ... [and] perfect white teeth [into] sharp, jagged fangs." Each transformation is depicted in a panel colored in stone grey. "Now," Dictys concludes, "Medusa is so hideous that any man who looks upon her is instantly turned to stone." "Do you think anyone will ever slay Medusa?" young Perseus then asks, suggesting both a glimpse of his future and the implicit moral righteousness of her being slain.

Once again, to maintain the hero narrative, Medusa's past is depicted in a manner that suggests her future evil by highlighting her immorality (sexual transgression and vanity). But a trace of something more dehisces for a moment: Medusa was originally human and beautiful and had a past intertwined with Athena. In other mythic renderings, which don't fit the Perseus hero / Medusa monster binary, Medusa is said to have been raped by Poseidon in the temple of Athena, who punished Medusa for the defilement by making her hideous.

And indeed, the interrelationship of gender, sex, and violence is a key theme backgrounded in the myth - not just Medusa's past, but Danaë's past (sexual relations with Zeus) and present (King Polydectes attempt to force Danaë to marry him) as well as Andromeda being married to Perseus as a reward for his heroics. More broadly, the sexual potency of women, both coveted and feared,

\footnotetext{
${ }^{7}$ On articulation, redaction, the redactic, dehiscence, and thick frames of power, see Alexander Laban Hinton, Man or Monster? The Trial of a Khmer Rouge Torturer (Durham: Duke University Press, 2016); see also Alexander Laban Hinton, "Postscript - Man or Monster?," Journal of Genocide Research 20, no. 1 (2018), 181-192.

${ }^{8}$ See Sabah Carrim, "The Legacy of Hannah Arendt's Banality of Evil," Review of Human Rights 3, no. 1 (2017), 43-64.

${ }^{9}$ For different readings of the motif of the gaze, see Marjorie Garber and Nancy J. Vickers, eds., The Medusa Reader (New York: Routledge, 2003).

${ }^{10}$ What follows is taken from Hoena and Ferran, Perseus, 13-15.
} 
is depicted in scenes such as Danaë's being locked away from men to prevent her from having the son destined to kill Acrisius, Andromeda's sacrifice to Poseidon, Danaë's inability to ward off Polydectes's advances without Perseus as her protector, and the danger of the Grey Witches, Gorgons, and, of course, Medusa herself.

Once discerned through critique (an unpacking of frames and exploration of the gutters and the unsaid), Medusa becomes a much more complicated character. And indeed, she has figured in a myriad of critical discussions. ${ }^{11}$ For the purposes of this essay, I want to highlight how a methodology of critique may be applied not just to narratives like the story of Perseus and Medusa, but to other domains including the narratives that undergird work in critical genocide and prevention studies. I will reapproach this point from a different direction - though one still related to Medusa and the first lesson in prevention - in my next story and second section of this essay.

Before doing so, however, I want to note how critique complicates the perpetrator-victim binary and legitimation of violence. If the popularized myth portrays a simplified sequence of violence (V1 [legitimating] $\rightarrow \mathrm{V} 2]_{,}^{12}$ the more complicated mythic strands suggest a much longer and morally fraught cycle of violence: V1 (Medusa's rape) $\rightarrow$ V2 (Athena's curse) $\rightarrow$ V3 (Medusa's petrifying violence) $\rightarrow$ V4 (Perseus cutting off her head) $\rightarrow$ V5 \& V6 (Perseus using Medusa's head to petrify Andromeda's suitor and King Polydectes and their guards) $\rightarrow$ V7 (Medusa's head being mounted on Athena's shield and used for violence even as Medusa's violent power is symbolically domesticated).

Medusa, then, raises questions about how we represent and analyze violence, how our accounts dehistoricize, decontextualize, and even dehumanize others, the gaps in our analyses, the haunting and uncanny conceptual spaces we fear, our tacit assumptions about gendered violence and the legitimation of violence including mass murder (Perseus's killing of not just Andromeda's suitor and Polydectes but their entire guards), and questions about the intersection of violence, law, responsibility, and legitimacy.

To analyze something involves an unloosening, an endeavor that may be undertaken through the method of critique that always bears in mind questions of gaze and the first lesson in (critical) prevention: "There's a Medusa in the room!" I end with another warning: Medusa appears in my next story, set in Norway, even if she remains unnamed. I'll give you a hint: pig in a poke, Medusa's head in the bag.

\section{Interlude}

Evaluation

Time to change the tone. I'm worried about what reviewers will say (but also that I'll continue to stray from the well-trodden path to prevention). "Post-modern junk." "Boring." "I read Why Did The Kill? What happened?!" "Frivolous and foolhardy." "A waste of pen and ink (and my time)." "Too many clichés!" "Nothing to do with prevention." "Can't write." "And I thought Man or Monster? was odd! At least it had an explanatory ending." "Passé." "Number One . . on the top ten list of why I no longer read anthropology." "Retitle The Hinton Facade." "Fell asleep while reading." "What's the point?"

Archeology (aka "TheCriticalPreventer's MethodologicalGuidetoFinding theMedusain the Room") In early September 2018, I attend "The UN Genocide Convention at 70 Conference," conference hosted by HL-SENTERET, a Norwegian research center and museum that plays a role in Norway somewhat similar to the United States Holocaust Memorial Museum and Yad Vashem. Established in part as a response to economic losses suffered by Norwegian Jews during Nazi occupation, HLSENTERET is located in Villa Grande, where an infamous Nazi collaborator resided.

At the end of two packed days of papers and discussions focused on the politics of mass atrocity prevention on the $70^{\text {th }}$ anniversary of the UN Genocide Convention, our hosts take us to

\footnotetext{
${ }^{11}$ Garber and Vickers, The Medusa Reader.

${ }^{12} \mathrm{~V} 1 \rightarrow \mathrm{V} 2$ stands for Violence $(\mathrm{V})$ at Time 1 standing in relation to (in this case by legitimating and leading to) Violence at Time 2.
} 
the nearby museum featuring "the world's best-preserved Viking Ships" excavated from Viking tombs in the Oslo Fjord. ${ }^{13}$

Besides the ships, there are wooden carts, animal head sculptures, and ornate sleighs from burial mounds. A film, "The Vikings Alive" depicts how the artifacts may have gotten here. A ship sets sail, a battle ensues. There is a return home, shovels hitting the ground, burial of the dead. As I sit on a bench watching the show, projected onto the walls of the museum, I nod to a colleague and ask, "What do you think? Genocide?" A shrug. Uncertainty. Vikings are not part of the genocide studies canon, which is temporally inflected by the destruction of the European Jews even if the purview of the field has broadened over the past decade, as illustrated by publication trends, including content in the Journal of Genocide Research and Genocide Studies and Prevention (see also Woolford, Muller, and Sinclair, this issue).

Each of the three large Viking ships displayed has a turn-of-the-twentieth-century story of discovery. And excavation. The most ornate ship on display, the Oseberg, was discovered in 1903 by a farmer, who notified a prominent archaeologist, Gabriel Gustafson. ${ }^{14}$ Gustafson cordoned off and secured the site before undertaking a three-month dig with a team that likely used tools such as trowels, shovels, sifting screens, and measuring devices. Like the Vikings, burrowers of the ground.

A photo of Gustafson shows him standing at the base of the hollow his team had created. If the excavation took just months, the longer-term process of restoring and preserving the artifacts took many years, eventually becoming a primary exhibition at The Viking Ship Museum.

The Dig

Here we arrive at a first signpost - part of "The Critical Preventer's Methodological Guide for Finding the Medusa in the Room" - for critical prevention studies. Perhaps it is the biggest signpost. Maybe even the only one that needs discussion. "The dig." And this signpost has a flashing light, a warning to which we can return again and again.

For prevention, like all of our pursuits, involves excavation, fingers sifting earth and sand, an exploration of ruins in the hope of avoiding genocidal ruin. Ruin, from the Latin ruere, "to fall," suggesting collapse, decline, and catastrophe. ${ }^{15}$ What came before now. Ruins like the secret location of Medusa's lair. Ruins offering traces of the past that provide clues to the present and what might come next - if only we further hone our excavatory skills. One paradox of atrocity prevention is that, like Klee's angel of history, it looks at a past, both distant and proximate, to envision a future that can't be fully seen.

\section{Excavation}

Like other fields, genocide studies and prevention research is predicated on "the dig." Excavation. ${ }^{16}$ To excavate is to "make (a hole or channel) by digging" such as by "carefully removing earth from (an area) in order to find buried remains." The Latin root of the term, excavare, means to "hollow out." 17

This notion of "hollowing" resonates with ideas of articulation and redaction as well as the graphic narrative "grammar" of gutters and frames. ${ }^{18}$ Our excavatory assemblage - mediated by structures of power and associated ways of ordering and classifying reality - are predicated on hollowing, a set of erasures, gaps, redactions, and backgroundings. These excavatory hollows are

\footnotetext{
${ }^{13}$ What follows on The Viking Museum is based on its website. Museum of Cultural History, "The Viking Ship Museum," accessed November 10, 2019, https://www.khm.uio.no/english/visit-us/viking-ship-museum/index.html.

${ }^{14}$ What follows on Gustafson draws both on Museum of Cultural History, "The Viking Ship Museum - Oseburg," accessed November 10, 2019, https://www.khm.uio.no/english/visit-us/viking-ship-museum/exhibitions/oseberg/ oseberg-found.html and World Archaeology, "Gustafson at Oseberg," Current World Archaeology 52 (March 30, 2012), accessed November 10, 2019, https://www.world-archaeology.com/great-discoveries/gustafson-at-oseberg/.

${ }^{15}$ Concise Oxford English Dictionary, “Ruin” (Oxford: Oxford University Press, 2011).

${ }^{16}$ This paragraph and broader discussion on excavation draws on and extends Hinton, Wonder Woman. See also Hinton, Man or Monster?; Alexander Laban Hinton, The Justice Facade: Trials of Transition in Cambodia (New York: Oxford University Press, 2018).

${ }^{17}$ Concise Oxford English Dictionary, "Excavate" (Oxford: Oxford University Press, 2011).

${ }^{18}$ See Hinton, Man or Monster?; Hinton, The Justice Facade; Hinton, Postscript.
} 
visually manifest in "the gutter" - the aforementioned frame construction of graphic narratives, which have an ostensible narrative flow undercut and ruptured by a grid of crosscutting frames that simultaneously question assumptions about meaning, time, and space. ${ }^{19}$

The Hollows of Prevention. Here we find a second warning in critical prevention studies: beware the excavator who believes s/he can use the past to prognosticate the future. Pig in a Poke. Medusa's Head in the Bag. Along these lines, perhaps we need a rethinking of the often-cited George Santayana saying - "those who cannot remember the past are condemned to repeat it" - in which it is put in conversation with Adorno's warning, "There can be no poetry after Auschwitz." Atrocity prevention treads the gap between these two oft-cited sayings about genocide even as it flails at a related imperative, "Never Again." The Hollows are the spectre of our excavations, the source of hauntings from the ruins, the grounds of this guide for finding the Medusa in the room, a Sisyphean task.

\section{Authorization}

Excavation is an enterprise, a "hollowing" endeavor undertaken with an end. ${ }^{20}$ And, like all projects, this enterprise requires authorization for the "hollowing out" to unfold. There is, on the one hand, the "permit" that legitimates the endeavor, an approval or sanction linked to structures of power (including "academic authorization"). But there is also "authorization" in the sense of that which gives "authority," such as the set of conceptual principles that legitimate the study, including the way the excavation is undertaken.

Gustafson could not embark without permission to conduct a dig at a particular time and place or status within structures of power, such as his institutional position as an archeologist. This authority was signified by his ability to cordon off and guard his site as well as by accoutrements (outfit and equipment) and practices, including performative expertise.

Tools

A dig also requires techniques, tools, and practices. If they symbolize authorization, these tools, techniques, and practices - let's refer to them together as "tools" - condition the endeavor, both enabling and constraining how the excavation unfolds and what is found. These tools are deployed as part of a larger methodology. Gustafson was, of course, trained as an archaeologist and used archeological tools to excavate the ruins of the Oseberg, reclaim the ship and other objects as artifacts, and reconstruct a Viking past imagined in "The Vikings Alive" film that plays three times an hour at The Viking Ship Museum.

Fire

Excavations also require illumination, the "fire" of light that enables artifacts to be discovered. Gustafson, for example, likely used lanterns in the Oseberg dig. If light reveals, it also occludes, a partial illumination that foregrounds particular places while creating shadows and leaving other areas in darkness.

Excavations are lit by many fires. Here are a few. There is the fire of our concepts and theories, which direct our analytical gaze. A second is the fire of our passions, the motivations that drive us, push us to excavate. Yes, those motives are bound up with structure. Professional ambition. Honor. Shame. But there are also those that are personal. Including our fetishes. About that I will have more to say. Then there's the fire of the archive, a fever, the validating stamp of authorization. Impression. $^{21}$

\footnotetext{
${ }^{19}$ Scott McCloud, Understanding Comics: The Invisible Art (New York: HarperCollins, 1993); Spiegelman, MetaMaus. On critical genocide studies excavation, see also Hinton, Wonder Woman.

${ }^{20}$ On "enterprise," see Alexander Laban Hinton, et al. eds., "Introduction: Rethinking Peace Studies," in Rethinking Peace: Discourse, Memory, Translation, and Dialogue, edited by Alexander Laban Hinton, et al. (New York: Rowman and Littlefield, 2019), xiii-xxxii.

${ }^{21}$ The "drive" of the "author" may be passionate (propelled not just by "the fire" of libidinal or fetishistic desire, but more broadly by intensely felt emotions and even the passion to understand) or structural, such as the "fever" that emerges from the instability of authorization since it requires replication and a doubling that is never identical to the original (Jacques Derrida, “Archive Fever: A Freudian Impression.” Diacritics 25, no. 2 (1995), 9- 63; see also Johnson, The
} 
We don't know a great deal about the fires that drove Gustafson, though he left diaries, his own ruins, a Gustafson archive, traces for excavation. The fire of this essay turns in a different direction, toward prevention, so I'll leave his diaries aside. But we know his excavation earned him a degree of fame. A moment. Spotlight.

Assemblage

"The dig" is a moment of glory - Indiana Jones, Laura Croft, people like Gustafson, too. Another black and white photo shows him looking dapper on the Oseberg dig: jacket and bow tie combined with knee-high mud boots and a hat, brim curled. He has an air of confidence and erudition, poise and aplomb.

Dig and display. It seems easy. And indeed, Gustafson's team sifted the soil for not even four months. But that was just the beginning of the story. ${ }^{22} \mathrm{He}$ labored for twenty years to piece together the ship and the artifacts he had found. He was able to use 90 percent of the ship's original timber. This phase took place out of site, a process painstaking and tedious at times. His assemblage of artifacts now stands at the Viking Ship Museum: ruins excavated (by Oseberg), reassembled into a new set of ruins (The Viking Ship Museum), now excavated one more by the ink of my pen, the glance of your eye.

The archaeologist excavates the earth and objects it preserves with authorization, methods, tools, fire, and assemblage to produce such artifacts. This essay is the artifact of my excavation of prevention. My atrocity crimes "Viking Ship," part of the ruins of this special edited collection.

You are the reader of these textual ruins, undertaking your own excavation. A text read and reread. Roland Barthes called it "the writerly," the polyphony of texts distinguished from the singular authoritative voice of "the readerly," a "definitive" monologue. ${ }^{23}$ Excavation is writerly, though many assume it is readerly, the discovered truth presented at "the museum." It's a point to which I will return.

I have not forgotten my promise of more signposts to guide an archaeology of prevention. No pig in the poke. Medusa's head is out of the bag. Do you see my method, my tools, my lantern? My permit is printed at the top of the first page. This is my assemblage. Go back and make your own. Let Medusa be your guide.

\section{Pharmakon}

Word

Pill. A capsule. Compressed medicine. The magic bullet. But also bitter, difficult to swallow. That's why some people are referred to as "a pill." Pills often need to be sweetened and coated. "Sugar the pill," it's said. Regardless, the pill is meant to be swallowed whole.

Pill. The Oxford English Dictionary offers many inflections. A small ball of any substance. A pellet. Cannonball then later bullet, bomb, or shell. A tidal pool. A ball in billiards. Pellet of opium. Cigarette. Testicle. A ball of fluff on the surface. Pill as in to pillage and plunder. Sometimes a medical officer. An outer covering. And of course there's "the pill." Contraception. Intervention. I could go on. Pill bag. Pillbox. Pill head. Pill popper. Pill peddler. Pill Pusher. There's an old saying. Pill and poll. To ruin by depredation. To strip bare. Pill as noun, pill as adjective. You get the idea.

Let's look at the source. Dispensation. Pharmacy, "a place where medicinal drugs are prepared or sold." ${ }^{24}$ It's also a science, as in the ancient Greek pharmakeia, "the practice of a druggist," from pharmakon, "drug." Though things are a bit more complicated. For the Greeks, pharmakon meant both "remedy" and "poison." The idea of a "poison pill" gets at the idea.

Pharmakon. Poison and cure. Like Medusa's blood. Like this essay. Like prevention.

Here, then, is another signpost in our guide to critical prevention. Genocide as Pharmakon. Prevention as cure, prevention as poison. The Prevention Pill.

Critical Difference). Even if it comes from the same "authority," each dig is distinct, yields a different truth or, to use Derrida's term, "impression."

${ }^{22}$ What follows is based on details from Museum of Cultural History, "The Viking Ship Museum," accessed November 10, 2019, https://www.khm.uio.no/english/visit-us/viking-ship-museum/index.html.

${ }^{23}$ Roland Barthes, S/Z (London: J. Cape, 1975).

${ }^{24}$ The Oxford English Dictionary, "Pharmacy" (Oxford: Oxford University Press, 1989). 
This idea, I know, is itself a bitter pill to swallow, particularly given that we just celebrated the $70^{\text {th }}$ anniversary of the UN Genocide Convention, an occasion that marked a University of Manitoba workshop that gave rise to this special issue.

To sugar the pill, so to speak, let me tell some more stories even if, like the Perseus-Medusa myth and the recounting of the conference in Norway, they are critical prevention narratives. The first, like the Perseus myth, has ancient origins. The second is another of my own.

So let's turn to our next story, Plato's Phaedrus, to learn more.

\section{Thoth and Thamus}

Thoth thought he had it made. He had good stuff! Or at least he thought he did.

In Plato's Phaedrus, Socrates recounts how this God traveled to Thebes to appear before the King of Gods, Thamus. Thoth had invented remarkable things, not just numbers and calculation, but writing (and dice and draughts, too). "Writing," Thoth enticed his king, will "make the Egyptians wiser and improve their memories." 25

Poor Thoth. The king shot him down. The fact is, he told Thoth, "this invention will produce forgetfulness in the souls of those who have learned it because they will not need to exercise their memories, being able to rely on what is written." Moreover, the King added, Thoth would be "equipping your pupils with only a semblance of [wisdom], not with truth." ${ }^{26}$ Thoth's invention of writing was not "a remedy" (pharmakon) for memory, but a poison instead.

Pharmakon. Poison and cure. In ancient Greek, the term had an umbrella of meanings (e.g., medicine, recipe, drugs, philter), but perhaps most centrally this idea of something both remedial and harmful. Like a pill.

Now on to our second narrative, set in a completely different time and place: November 16, 2018, on the outskirts of Phnom Penh, Cambodia.

I was there for this one. ${ }^{27}$

Genocide Justice

Gravel spits on the underbelly of our van as we turn the corner into the dirt parking lot of the Extraordinary Chambers in the Courts of Cambodia, the ECCC, or Khmer Rouge Tribunal as everyone calls it.

The browned landscape is lit by saffron, rows of robed monks and elderly nuns dressed in white. The monks will sit in the front row of the court's public gallery as the decision in Case 002.2, which includes the charge of genocide against the two most senior surviving leaders of the Khmer Rouge, is read later in the morning.

The 500-seat courtroom is filled with a wide range of "stakeholders": VIPs, including diplomats and government officials, blue-shirted students, civil parties, villagers, journalists, and a handful of academics like me.

Just before the curtain rises, a Cambodian Public Affairs officer provides a brief sketch of the case in which the two most senior living Khmer Rouge, "Brother Number Two" Nuon Chea and Head of State Khieu Samphan, are being tried for atrocity crimes committed during Democratic Kampuchea (April 17, 1975 to January 6, 1979).

"Oh, and it will take about an hour and forty minutes to read the verdict," the court officer finishes. I hear a few moans.

Then the curtain opens. The parties are in place.

Better late than never.

These words, well-worn like the elderly defendants, came to mind as I gaze at Nuon Chea (92) and Khieu Samphan (87). Many feared they would die unjudged.

\footnotetext{
${ }^{25}$ Jacques Derrida, "Plato's Pharmacy," in Literary Theory: An Anthology, eds. Julie Rivkin and Michael Ryan (Malden: Blackwell, 1998), 431.

${ }^{26}$ Derrida, Plato's Pharmacy, 436.

${ }^{27}$ The narrative below partly draws on Alex Hinton, "Justice at Last," Mekong Teahouse, November 19, 2018, accessed November 9, 2019, http://mekongteahouse.com/observations/justice-at-last/.
} 
Two years before, I sat in the witness stand and watched as Nuon Chea sought to deflect blame and deny responsibility for a campaign of terror and mass murder that resulted in the death of almost a quarter of Cambodia's 8 million inhabitants from 1975-1979.

What about the American bombings? He chided me after I had testified for three and a half days on the charge of genocide. And didn't Vietnam want to swallow Cambodia?

The verdict would put an end to those arguments. Yes, the U.S. carpet-bombing of Cambodia constitutes a war crime. Yes, Vietnam meddled in Cambodian affairs and sought to topple the Khmer Rouge regime. And of course Cambodia was caught in geopolitical crosshairs. But one and only one group deserves the primary blame in the end: the Khmer Rouge leaders who made the decisions.

The judgment makes this clear in legal monotone. For almost two hours, the court's President, Non Nil, reads a summary of the verdict. He barely looks up as he methodically details the crimes: mass relocations, brutal work camps, an extensive security system and prison network, forced marriage, and the targeting of Buddhist monks as well as Cambodia's ethnic Chams and Vietnamese.

By the time President Non Nil finishes, Nuon Chea has been excused to listen to the proceedings in a holding cell. Both defendants are in poor health and may die any day.

When the final disposition is delivered at the end, Khieu Samphan is asked to stand in the dock. He has to be supported by two guards, one of whom hoists him up by the back of his trousers, as Non Nil declares the pair's life sentence for war crimes, crimes against humanity, and the crimes of crimes, genocide.

Genocide. Justice. But also pharmakon. Like Medusa.

\section{Convention}

These two stories, distant in time and place, are easily set into conversation. Indeed, they connect genocide, justice, and prevention with the idea of pharmakon in interesting ways. Given that this special issue began with a 70th Anniversary workshop, let's start with convention. (Genocide) convention as poison, (genocide) convention as cure.

Convention is etymologically related to the word "convene" and its Latin cognate, convenire, means to "assemble, agree, fit," or more simply "to come" (venire) "together" (con). To convene. Assemblage. Parts brought together in a meeting or activity. ${ }^{28}$

Along these lines, convention may refer to "a large meeting" such as a political convention or "an agreement between states" that codifies "a way in which something is usually done" or "socially acceptable behavior."

And there we have it: convention as in it's criminal to commit genocide. The December 9, 1948 Convention on the Prevention and Punishment of the Crime of Genocide. Lemkin's Convention. Our convention. Genocide studies convention, genocide assemblage, convention codified in written word.

Written word. This takes us back to Phaedrus and pharmakon. It also speaks to convention. For King Thamus worried precisely about such written codification, an intended auxiliary that was a diminishment, a crutch both salve and source of sickness.

Despite the legends of renown and glory, the exhortations of "it's the best we have," we remain afflicted by genocide fetish. Excessive fixation on a part (ignoring the whole), attribution of magical powers, object of excessive desire, overcommitment. A charm, to revisit the French source (fetiche), the product of sorcery.

The story of Lemkin provides a related example of genocide. The hero of the genocide convention myth. The First Preventer. Lemkin fetish. Convention fetish. The elixir of prevention cure. And now, most recently, R2P fetish. 
I grant you Convention as cure. I sip from that elixir, too. But I warn you it is also poison. Some of the poison is easy to see, acknowledged begrudgingly or, more often, in passing, with a wave of the hand. Political groups provide an obvious example.

And there it was at the Khmer Rouge Tribunal. "Genocide" flashed the headlines after the verdict. "Khmer Rouge leaders found guilty of genocide" splashed The Guardian." "Khmer Rouge's Slaughter in Cambodia is Ruled a Genocide," proclaimed The New York Times.

While literally accurate, the headlines, the written word, offered a truncated truth, diminishing a more complex reality - Thamus's point. For starters, what was legally a partial and somewhat roundabout conviction for genocide - against two ethnic minorities (Muslim Chams and ethnic Vietnamese) - had become something quite different, the all-encompassing headliner of "genocide."

We all know the story of how political and "other groups" were excised during UN deliberations as the Convention was being promulgated. Usually it's referenced, if at all, with a quick "too bad, but the Convention is what we have." A point well-taken. Better than nothing, like the ECCC genocide verdict.

But it's still a poisoned point, not solely cure. First and foremost, there is the prioritization of certain protected groups and not others - not just political but economic, social, and so forth. And it's not just the glaring gap left by exclusion of political groups. Left-handed people beware; so, too, should those who are transgender (or any gender for that matter) - and many other identity groups. And then there's the erasure of cultural genocide.

There still more poison. We have the arbitration of Convention, a normative order applied. It's sticky with politics through and through. The examples are legion, gatekeeping debates about what's "authentic" genocide. I'll give a quick example: race and slavery in the U.S. (which Lemkin deemed not genocide) or apartheid in South Africa (Leo Kuper's "not quite" case).

By what criteria? Who decides? What are the positive and negative effects of such convention? And what does it mean to crown "the crimes of crimes," making other sorts of horrible violence seem tepid in comparison.

The drips and drabs of much settler colonialism violence (see Arnold and Woolford, Muller, and Sinclair, this issue), including that in the United States where I reside, provides an example and in many ways remains on-going. It turns us away from structural violence and the ways in which power reveals, obscures, and erases (see also Feierstein, this issue). Genocide Convention signals a temporality - a discrete beginning and end - and particular modalities of violence that obscure these other sorts of violence. Thoth's vice; Thamus's warning.

The notion of atrocity crimes provides some mitigation, though genocide still reigns supreme. And atrocity crimes wear a crown of their own, imposing another triumvirate hierarchy with a lesser fourth part, ethnic cleansing.

I could go on. But you get the point. The UN Genocide Convention - and convention more broadly - as poison and cure.

Before we leave the topic of convention, I leave you with one last inflection. Thoth, the god of numbers and writing, is also a "god of articulation" to again reference a notion I discuss in Man or Monster? He advocates a rendering of experience and understanding in remembered written form: spelling something out, if you will. But the act of articulation always involves redaction as Thamus's comments suggest. The poison, I would add, remains in what Man or Monster? refers to as the redactic, the suppressed excess that haunts the articulation, sometime suddenly dehiscing in moments of the uncanny.

Remember my initial warning and our first lesson: "There's a Medusa in the room!" On that I'll have a little more to say. But meanwhile, let's look for her elsewhere. Indeed, Medusa haunts the ECCC courtroom. So, too, do the spirits of the dead.

Justice

Justice. Another modality of genocide prevention. Another elixir of promise. It's said to combat impunity, contribute to democratization, advance the rule of law, and deliver peace, security, reconciliation, and healing. Justice as fetish, a sorcerous conjuring.

But also justice as poison, something that can never be fully delivered and that inevitably falls short in proportion to the fetishistic intensity of its projected cure. Justice as transitional justice 
throws this even more into relief, with the boatload of promised goals that are part of what The Justice Facade refers to as the "transitional justice imaginary," ${ }^{29}$ replete with utopian, teleological, globalizing, democratizing, and progressivist aspirations and assumptions.

The ECCC provides an illustration with its motto, "moving forward through justice," and official proclamations that the court will contribute to Cambodia's "justice and national reconciliation, stability, peace and security." ${ }^{30}$ Such aspirations mask a profoundly political process that involved Cold War strategy and domestic and international concerns.

The court was a compromise formation from the start, structured with a hybridity and mass of contradictions that would have made that fan of the pharmakon, Derrida, nod knowingly. Indeed, Derrida's peer, ECCC defense lawyer Jacques Verges - who pioneered the legal strategy of "disruption," or undercutting the legitimacy of a trial in the court of public opinion - did smile mischievously as he deployed this strategy at the ECCC, launching early salvos in what would be a litany of defense complaints.

The defense lawyers have had cause to complain, as Nuon Chea and Khieu Samphan's lawyers did (yet again) immediately after the Case 002.2 verdict. The process has been a slog, the court's name partly stained by the allegations. Political interference. Corruption. Unfair rulings. Truncated jurisdiction. And a legal process sometimes unsound. Nuon Chea's defense lawyer called the court a farce, mere victor's justice. And the KRT's justice is indeed a partial one. Many people hoped for more.

After a dozen years and over $\$ 300$ million spent, the court convicted just three people. The international community wanted a dozen arrests or more. The Cambodian government insisted on just five. Two of the accused died, unjudged.

The hybrid court is based in Cambodia. The government holds most of the cards and can pull the plug at any time. It's widely expected that they have already done so and that the November 2018 genocide conviction was the court's last hurrah, the final act in what many people refer to as "the show."

There's more. The laundry list of court problems is long. One of the biggest elephants in the room is superpower culpability.

As Nuon Chea noted, the U.S. carpet-bombed the Cambodian countryside during the Vietnam War, dropping more tonnage than it dropped during World War II.

China, in turn, provided the Khmer Rouge with support, aid, and arms. Western powers did the same with resistance factions to help fuel a civil war that continued long after the Khmer Rouge were deposed in early January 1979.

Superpowers don't want this dirty laundry aired. So when, after years of geopolitical dithering, they finally allowed the ECCC to be set up, they limited its jurisdiction to only include the time Khmer Rouge were in power.

Defense lawyers have repeatedly highlighted the hypocrisy. Their contention that the ECCC should have dealt with superpower crimes has merit.

So too do defense arguments that is impossible for the ECCC to reveal a fuller truth and discern the causes of violence when only a snapshot of history is brought into view. The extensive problems have led some to ask if the trials have been worth the effort and question whether justice can ultimately be served.

Genocide Justice as remedy, justice as poison.

Prevention in Translation

Pharmakon is a tricky word. Remedy, recipe, and cure. But also drug, philter, and, of course poison. ${ }^{31}$

So, too, is Thoth: God of wisdom, records, the moon, and much more. Thoth and his pharmakon are pesky, an irritant, hard to pin down. Like convention, the problem of "prevention in translation" is usually swept under the rug.

Let's go back to the ECCC, the verdict read in Khmer, translated into English, then from English to French. Thamus would not be pleased with these secondary and tertiary renderings. Nor, indeed, should we. 
Take the very notion of "justice." What, exactly, does it mean? We have our dictionary definitions: "The administration of law or of legal processes; juridical proceedings" or, more generally, "maintenance of legal, social, or moral principles by the exercise of authority or power," an idea linked to its etymological connections to "just," or "what is morally right." 32 Justice, like pharmakon, encompasses a loose conglomeration of terms, including legal process, "just desserts" given, righteousness, and a hint of the Sublime.

When artist, S-21 survivor, and Cambodian civil party Vann Nath was asked in court what he wanted from the trial of Duch, the commandant of the torture and extermination center where he was imprisoned, Vann Nath replied, "What I want ... it's ..." He paused. Then motioning in the air, he continued, "[it's] something that can't be seen. It's justice for those who died. For this justice, I am relying on this Chamber. But in my heart, I'm not certain what this justice is." He glanced up at the judges. "It is only when this court is over that we may know the answer to the question: justice, what is it? I'm not certain. What is justice? In my heart I hope that it's something that will be an outcome resulting from the actions of Your Honors, of this court." ${ }^{33}$

Vann Nath's comments raise a question that should be at the heart of considerations of international justice prevention: what, exactly, is justice? And how is a Judeo-Christian legal concept understood in a predominantly Buddhist context like Cambodia? Indeed, this is something I thought about when I saw the saffron-robbed monks observing the Case 002.2 verdict from the front row of the public gallery.

If, in The Justice Facade I discuss the transitional justice imaginary, I argue that these projections mask what is really taking place on the ground. Katherine Sikkink's notion of "the justice cascade," a foil upon which my title partly plays, highlights this point, suggesting a relatively seamless process of "remedy" and "cure" - a global "cascade" of accountability and transitional justice. The waters, however, are muddy and what lies beneath the veneer of the water's surface are rich ecosystems of cultural complexity and lived experience.

In Cambodia, Buddhism is central to understandings of "justice." Indeed, the Khmer gloss, yutethoa, is formed in part from the key Buddhist principle of dhamma, a term that, like justice and pharamkon, has a wide range of referents.

For many Cambodian villagers who survived DK, then, the tribunal is linked to Buddhism in different ways. Some view the tribunal as ultimately unnecessary since those who sin get their "just desserts" through reincarnation, as their past (bad) actions condition their future. Others view the tribunal itself as an instantiation of this karmic process.

For many Cambodian survivors, especially rural villagers who are largely unfamiliar with formal legal justice, the tribunal's key purpose relates to transactions with the spirits of the (DK) dead, the haunting presence of those not yet reborn. They often perform a Buddhist ritual (bangsokol) in which "justice" is transferred, though monks, to the dead in order to calm the spirits and facilitate their rebirth, thereby rebalancing the social world, an ideal reflect both in terms of everyday health (to feel "easy") and Buddhist being (with its emphasis on equanimity).

Here we return to Thamus's warning. The act of translating concepts like "justice" involves reduction and change. In the context of transitional justice, then, the proclaimed "cure" (delivering justice) is also poison, a "remedy" that redacts, erases, decontextualizes, and misrepresents everyday experience, practice, and understandings (see also Zulver, this issue).

But the translations of prevention go far beyond justice, encompassing domains such as peacebuilding (UNTAC), human rights (via Buddhist idioms), democratization, and so forth. Sadly, the issue of translation -- and related questions about lived experience and practice - is often ignored in the corresponding literatures, especially prevention studies. Medusa lurks, haunting our words.

Genocide as Pharmakon: Endings that are Beginnings

Genocide prevention, in all its modalities, is often depicted as a straight-forward good, a shared

32 Shorter Oxford English Dictionary, "Justice" (Oxford: Oxford University Press, 2007).

${ }^{33}$ Day 35, 55-56; Khmer 45. 
cause in need of little critical reflection since it is an obvious life-and-death imperative.

As this essay this has shown, the situation is less straight-forward, since prevention - and I have discussed what are sometimes referred to as "upstream" (legal promulgation of Convention) and "downstream" (international justice) mechanisms - is pharamakon, a remedy that is also part poison, sometimes dangerously so.

I have provided a few examples. There are many more. Thoth, for example, is also the god of numbers. Like the written word, numbers are articulations that foreground and background, redacting aspects of reality even as they are fetishized - numbers fetish! - as "hard" data. Thamus's warning is relevant here as well..$^{34}$

Earlier I spoke of not just prevention, but genocide as pharmakon. And indeed, this notion could be applied to genocide more broadly. Here are a few last brief inflections, considered through the second story, the ECCC verdict.

Nuon Chea, genocidaire, claims to be a hero. Or at least he contends that, like his comrades, he acted for noble purposes: the alleviation of oppression and poverty, the creation of a society free from imperialist and class-based domination, the collapse of the distinction between the rich and the poor. His defense was to deflect blame, casting it on others, particularly the U.S. and Vietnam and their lackeys. In his rendering, he was a tragic hero, largely misunderstood and scapegoated - a pharmakon defense.

Here is a perhaps controversial inflection of genocide as pharmakon: the notion that genocide can be committed in the name of the good. ${ }^{35}$ This idea grates on the ear, tears at our sense of morality. But, sadly, as much research has shown, there is a moral logic to genocide, as mass murder is legitimated as "remedy" (as is the genocide preventer's destruction of the genocidaire), a targeting cure to sociopolitical woes. It is, of course, a poisonous "cure" since the groups were demonized as impure and targeted for elimination.

More broadly, drawing on scholars like Stiegler, ${ }^{36}$ we might consider technology -- like the written word -- as pharmakon: an exteriorization that has the potential to transform humanity. Pharmakon as technology converges with pharmakon as recipe in the notion of social engineering: a "plan" or design to transform (a poisoned) society into a new (cured) state. Of course, the cure (social engineering) for the poison (the flawed society) is itself not just a cure but poison - genocide. Genocide as pharmakon.

Genocide, technology, and pharmakon intersect in others ways, perhaps most famously in Zyklon B and industrialized mass murder but also in new modalities like social media that provide both remedy (a source of grassroots atrocity crime alerts of the sort that became famous in Aleppo) and poison (Facebook used for incitement in Myanmar).

What else does Nuon Chea's pharmakon defense suggest about genocide? He raises the issue of the scapegoat, pharmakos, part of the semiotic family of pharmakon. Ironically, Nuon Chea claims to be a scapegoat. And perhaps in a limited sense he is: someone targeted by law as a symbolic offering of justice for a broad range of crimes committed by a wide range of actors - even if he was a ringleader.

Now we're back to prevention as poison and cure in its juridical manifestations. So let's refocus on genocidal process. Even as Nuon Chea claimed to be a scapegoat, he scapegoated others (the U.S. and Vietnam) to cast off (legal) blame. But this scapegoating indirectly implicated him, since the DK regime used precisely the same "recipe" to rid their society of its perceived source of woes.

A laundry list of "poisonous" groups - depicted as linked directly or indirectly to the U.S. and Vietnam - were targeted for "cure," what Khmer Rouge discourse sometimes referred to as

\footnotetext{
${ }^{34}$ For critiques of the fetishization of quantitative approaches, see, for example, Brehm and Woolford, Muller, and Sinclair, this issue, as well as Sally Engle Merry, "Measuring the World: Indicators, Human Rights, and Global Governance," Current Anthropology 52, Supplement 3 (2011), S83-S95. On "upstream" and "downstream" prevention, see Waller, this issue.

${ }^{35}$ On this point, see also Waller, this issue and James C. Scott, Seeing Like a State: How Certain Schemes to Improve the Human Condition Have Failed (New Haven: Yale University Press, 1998). On how such rhetorics permeated Khmer Rouge ideology, see Hinton, Man or Monster?

${ }^{36}$ Bernard Stiegler, "Relational Ecology and the Digital Pharmakon," Culture Machine 13 (2012), 1-19.
} 
being "swept up" and "cleaned" (boas somat). It's not just pharmacists who dispense "medicinal remedies": so, too, do genocidaires. Both are pharmakoi to return to the conceptual fulcrum of this essay section.

As the aforementioned euphemisms suggest, genocide as pharmakon is often manifest in discourses of purity and contamination and related binaries. And as highlighted in Derrida's reading and the very idea of pharmakon, Phaedrus foregrounds such binaries, including Thamus and Thoth's dialogue about speech versus writing. Derrida, of course, highlights pharmakon because it illustrates the slippage and implosion of such binary distinctions - just as they collapse in the genocidaire's attempt to parse good and evil identities, since human beings, like the term pharmakon, contain contradictory qualities that are impossible to contain in reductive categorical definitions.

Genocide as pharmakon. Dispensation. Arrangement and Order. A "recipe" for genocide.

\section{Medusa's Blood}

We've reached the end of these critical prevention studies meanderings, the back and forth this textual flow. We began and now end with Medusa even as she's been with us the entire time. She haunts my words and your reading. She is the preventer's ghost and double -- as well as the critical preventer's guide.

So, I urge you, always bear in mind the first lesson of prevention: "there's a Medusa in the room." It is one that has a doppelgänger, its critical prevention "last lesson" twin. ${ }^{37}$ Take a look. See what you can discern.

In their different ways, both lessons teach that, as we begin our "digs" and render our articulations, we redact, foregrounding and backgrounding, pushing complexities out of sight like the multiple dimensions of the story of Medusa condensed into a mythic moment of Perseus' heroics and glory.

Medusa can also, of course, be read through the notion of pharamakon. Medusa as scapegoat. Medusa as gender transgressor. Medusa as poison (petrification) and cure (her powers weaponized), qualities manifest in her very blood. Medusa as embodying a host of binary oppositions that collapse in her polysemy, like pharmakon in Derrida's rendering.

This polysemy is a key point at which myth and critique meet, both demanding an "unloosening" (to reinvoke to the etymology of "analysis") and openness that enables us to see what has been pushed out of sight, the ground of rethinking.

At the same time, it is important to bear in mind that the word "critical" has two key inflections related to its Greek root, krinein, which suggest both one who discerns and one who judges. This is a fraught role since discernment may be used in a "judgemental" sense to make normative claims. Indeed, the Khmer Rouge contended that the "science" of Marxist-Leninism had made them allknowing and thereby legitimated their project of social engineering. We know how that tragedy ended.

In this regard, myth and critique themselves stand in an interesting critical relation. Critique decenters myths that have been flattened into shallow narratives (like the redacted versions of the Medusa myth or the "culture industry" the Frankfurt school unpacked). Myth, in turn, decenters critique that bulldozes complexity in an attempt to "reveal" the truth in a singular manner (like a singular reading of myth and other cultural forms through a Marxist lens or the sorts of claims to truth made by the Khmer Rouge).

In this regard, we might even speak of a mythological grammar of critique, one that, through its polysemy, multivocality, contextualization, openness, ambiguation, reflexivity, and use of juxtaposition and drama, challenges such "judgmental" critique. ${ }^{38}$ Used together in such a manner,

\footnotetext{
${ }^{37}$ Alexander Laban Hinton, "Afterword: Look Again Aleppo - The Last Lesson in Prevention," in Rethinking Peace: Discourse, Memory, Translation, and Dialogue, ed. Alexander Laban Hinton, et al. (New York: Rowman and Littlefield, 2019), 221-238.

${ }^{38}$ I would like to thank one of the peer reviewers for suggesting I expand on this aspect of the relationship between myth and critique. On myth, narrative, and critique, see Peter Fitzpatrick, The Myth of Modern Law (New York: Routledge, 2002); George Pavlich, "Dissociative Grammar of Constitutional Critique?," in Genres of Critique: Law, Aesthetics
} 
each providing a reflexive check on the other, myth and critique constitute a powerful tool for critical inquiry, including the critical preventer's "digs."

This point has haunted us since you read the first line of this essay. Pig in a poke, I warned you, the "critical difference" was already there. And so I conclude by returning to this essay's beginning discussion of Medusa to underscore the point that the critical preventer's endeavor is a recursive one and indeed has failed if it seems to have reached a fixed end.

We saw how Medusa and her myths speak to the study of perpetrators, since she is at once victim and perpetrator, violated and violent, human and Gorgon monster - collapsing our neat victim-perpetrator binaries and related dehistoricizations (multiple acts of violence before and after "the event"), hero myths (Perseus the hero, also a perpetrator), depoliticizations (remember Poseidon, King Polydectes, and Athena's machinations and curse), and justice facades (Medea "brought to justice" even as she is a victim to multiple crimes).

For critical preventers, Medusa serves as a warning and reminder: be careful not to become inflated by the glories of convention and heroic prevention. Look for pharmakon, the flip side of the coin. For we, too, run our own epistemological pharmacies. We're prevention pharmakoi, dispensers of poison and cure.

And so, even as we celebrate prevention's halting successes and moments like the the $70^{\text {th }}$ anniversary of the UN Genocide Convention that began this special issue, we must bear in mind that they are haunted occasions and therefore that the critical preventer must always remember...

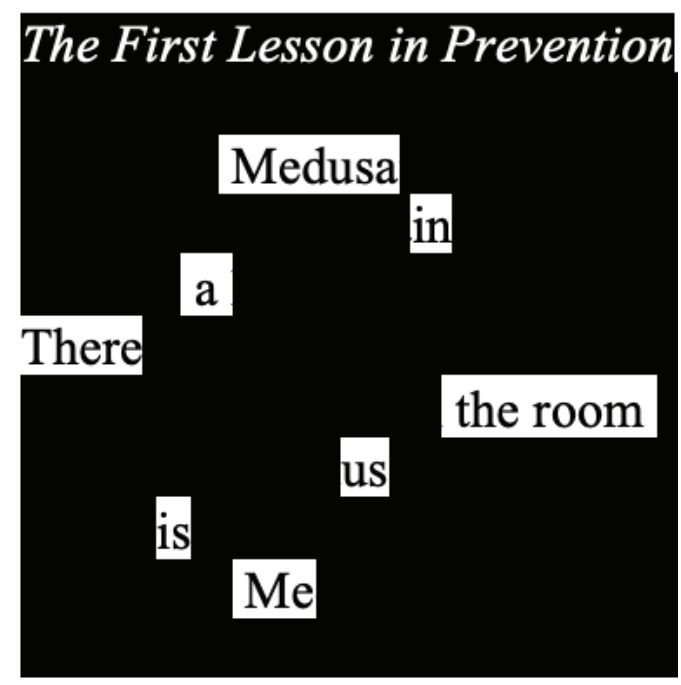

and Liminality, eds. Karin van Marle and Stewart Motha (Stellenbosch: Sun Press, 2013), 29-46; Johnson, The Critical Difference. 


\section{Acknowledgements}

I'd like to thank Andrew Woolford, Nicole Cooley, and the reviewers for their thoughtful comments and suggestions on this essay. I'd also like to thank Christian Gudehus, Susan Braden, and the team at Genocide Studies and Prevention for their efficient review of this essay and publication of the special issue in which it appears. My appreciation as well goes to the University of Manitoba and Rutgers Center for the Study of Genocide and Human Rights for co-sponsoring the workshop at which this essay and the larger special issue began to be formulated.

\section{Bibliography}

Barthes, Roland. S/Z. London: J. Cape, 1975.

Carrim, Sabah. "The Legacy of Hannah Arendt's Banality of Evil." Review of Human Rights 3, no. 1 (2017), 43-64. Doi: 10.35994/rhr.v3i1.83

Chute, Hillary. “Secret Labor." Poetry Magazine, July 1, 2013. Accessed November 10, 2019. https:// www.poetryfoundation.org/poetrymagazine/articles/70022/secret-labor.

Clarke, Kamari Maxine. Fictions of Justice: The International Criminal Court and the Challenge of Legal Pluralism in Sub-Saharan Africa. Cambridge: Cambridge University Press, 2009.

Concise Oxford English Dictionary. “Convene." Oxford: Oxford University Press, 2011.

--------. "Convention." Oxford: Oxford University Press, 2011.

-------. "Excavate." Oxford: Oxford University Press, 2011.

------. "Ruin." Oxford: Oxford University Press, 2011.

Derrida, Jacques. "Archive Fever: A Freudian Impression." Diacritics 25, no. 2 (1995), 9- 63. Doi: $10.2307 / 465144$

. "Plato's Pharmacy." In Literary Theory: An Anthology, edited by Julie Rivkin and Michael Ryan, 429-450. Malden: Blackwell, 1998.

Extraordinary Chambers in the Courts of Cambodia. Agreement between the United Nations and the Royal Government of Cambodia Concerning the Prosecution Under Cambodian Law of Crimes Committed During the Period of Democratic Kampuchea. Phnom Penh, Cambodia: ECCC, June 6, 2003. Accessed November 9, 2019. http://www.eccc.gov.kh/english/agreement image. aspx.

Fitzpatrick, Peter. The Myth of Modern Law. New York: Routledge, 2002.

Foucault, Michel. "Governmentality." In The Foucault Effect: Studies in Governmentality, edited by Graham Burchell, Colin Gordon, and Peter Miller, 87-104. Chicago: University of Chicago Press, 1991.

Garber, Marjorie and Nancy J. Vickers, eds. The Medusa Reader. New York: Routledge, 2003.

Hinton, Alexander Laban, Giorgio Shani, and Jeremiah Alberg, eds. "Introduction: Rethinking Peace Studies." In Rethinking Peace: Discourse, Memory, Translation, and Dialogue, edited by Alexander Laban Hinton, Giorgio Shani, and Jeremiah Alberg, xiii-xxxii. New York: Rowman and Littlefield, 2019.

Hinton, Alexander Laban. "Afterword: Look Again Aleppo - The Last Lesson in Prevention." In Rethinking Peace: Discourse, Memory, Translation, and Dialogue, edited by Alexander Laban Hinton, Giorgio Shani, and Jeremiah Alberg, 221-238. New York: Rowman and Littlefield, 2019.

- The Justice Facade: Trials of Transition in Cambodia. New York: Oxford University Press, 2018.

--------. "Postscript - Man or Monster?" Journal of Genocide Research 20, no. 1 (2018), 181-192. On What Remains and the Possibility of Representation, edited by Fazil Moradi, Ralph Buchenhors, and Maria Six-Hohenbalken, 165-174. New York: Routledge, 2017. Doi: 10.4324/9781315594897

--------. Man or Monster? The Trial of a Khmer Rouge Torturer. Durham: Duke University Press, 2016. -. "Critical Genocide Studies." Genocide Studies and Prevention 7, no. 1 (2012), 4-15. Accessed November 9, 2019. https://scholarcommons.usf.edu/gsp/vol7/iss1/3/. ."Justice at Last." Mekong Teahouse, November 19, 2018. Accessed November 9, 2019. http:// mekongteahouse.com/observations/justice-at-last. 
Hoena, Black A. and Daniel Ferran. Perseus and Medusa: A Graphic Novel. North Manket: Capstone, 2014.

Johnson, Barbara. "The Critical Difference." Diacritics, 8, no. 2 (1978), 2-9.

Merry, Sally Engle. "Measuring the World: Indicators, Human Rights, and Global Governance." Current Anthropology 52, Supplement 3 (2011), S83-S95. Doi: 10.1086/657241

McCloud, Scott. Understanding Comics: The Invisible Art. New York: HarperCollins, 1993.

Moses, A. Dirk. "Toward a Theory of Critical Genocide Studies." Online Encyclopedia of Mass Violence, April 18, 2008. Accessed November 9, 2019. http://www.sciencespo.fr/mass-violence-warmassacre-resistance/en/document/toward-theory-critical-genocide-studies.

Museum of Cultural History. "The Viking Ship Museum." Accessed November 10, 2019. https:// www.khm.uio.no/english/visit-us/viking-ship-museum/index.html.

"The Viking Ship Museum - Oseburg." Accessed November 10, 2019. https://www.khm. uio.no/english/visit-us/viking-ship-museum/exhibitions/oseberg/oseberg-found.html.

Mutua, Makau. "Savages, Victims, and Saviors: The Metaphor of Human Rights." Harvard International Law Journal 42, no. 1 (2001), 210-245.

Oxford English Dictionary. "Pharmacy." Oxford: Oxford University Press, 1989.

Pavlich, George. "Dissociative Grammar of Constitutional Critique?." In Genres of Critique: Law, Aesthetics and Liminality, edited by Karin van Marle and Stewart Motha, 29-46. Stellenbosch: Sun Press, 2013.

Scott, James C. Seeing Like a State: How Certain Schemes to Improve the Human Condition Have Failed. New Haven: Yale University Press, 1998.

Shorter Oxford English Dictionary. "Justice." Oxford: Oxford University Press, 2007.

Sikkink, Kathryn. The Justice Cascade: How Human Rights Prosecutions are Changing World Politics. New York: W. W. Norton, 2011.

Spiegelman, Art. MetaMaus: A Look Inside a Modern Classic Maus. New York: Pantheon, 2011.

Stiegler, Bernard. "Relational Ecology and the Digital Pharmakon." Culture Machine 13 (2012), 1-19.

Storrie, Paul D. and Thomas Yeates. Perseus: The Hunt for Medusa's Head. Minneapolis: Graphic Universe, 2008.

World Archaeology. "Gustafon at Oseberg." Current World Archaeology 52 (March 30, 2012). Accessed November 10, 2019. https://www.world-archaeology.com/great-discoveries/ gustafson-at-oseberg/. 